Laboratory Stabilization/Solidification of Surrogate and Actual Mixed-Waste Sludge in Glass And Grout

R. D. Spence, T. M. Gilliam, C. H. Mattus, and A. J. Mattus

Oak Ridge National Laboratory Oak Ridge, TN 37831-6202

Prepared for presentation at the 1998 AIChE Spring National Meeting

New Orleans, LA, March 8-12, 1998

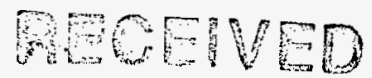

Mign 0 gran

$09 \mathrm{TI}$

Advances in Waste Treatment Technology, Including Thermal Processes

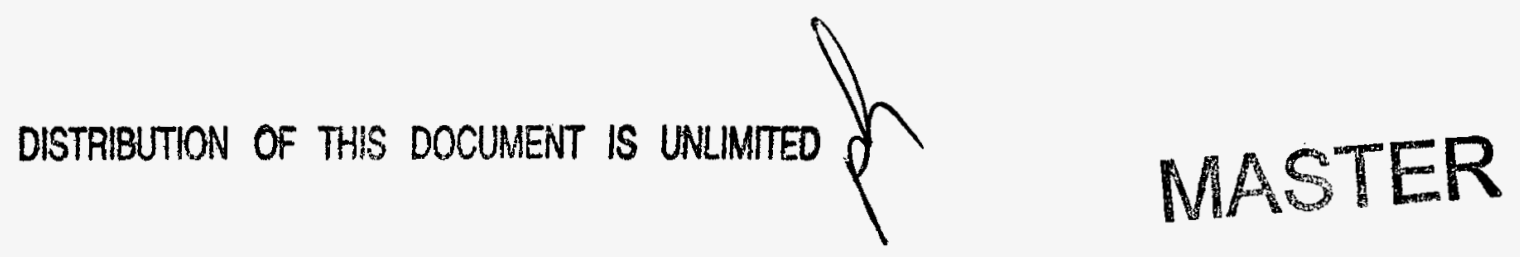

Unpublished

March 3, 1998

AIChE shall not be responsible for statements or opinions contained in papers or printed in its publications.

Prepared by

OAK RIDGE NATIONAL LABORATORY

Oak Ridge, Tennessee 37831-6202

managed by

LOCKHEED MARTIN ENERGY RESEARCH CORP.

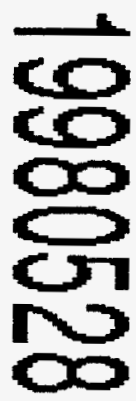

for the U.S. Department of Energy

under contract DE-AC05-96OR22464

DTIC QUALTTY INOPECTED 1 


\section{DISCLAIMER}

This report was prepared as an account of work sponsored by an agency of the United States Government. Neither the United States Government nor any agency thereof, nor any of their employees, makes any wartanty, express or implied, or assumes any legal liability or responsibility for the accuracy, compieteness, or usefulness of any information, apparatus, product, or process disclosed, or represents that its use would not infringe privately owned rights. Reference herein to any specific commercial product, process, or service by trade name, trademark, manufacturer, or otherwise does not necessarily constitute or imply its endorsement, recommendation, or favoring by the United States Government or any agency thereof. The views and opinions of authors expressed herein do not necessarily state or reflect those of the United States Government or any agency thereof. 


\title{
Laboratory Stabilization/Solidification of Surrogate and Actual Mixed-Waste Sludge in Glass and Grout
}

\author{
R. D. Spence, T. M. Gilliam, C. H. Mattus, and A. J. Mattus \\ Oak Ridge National Laboratory* \\ Oak Ridge, TN 37831-6202 \\ Telephone: (423) 574-6782 \\ FAX: (423) 574-7241 \\ e-mail:suu@ornl.gov
}

\section{Introduction}

Grouting and vitrification are currently the most likely stabilization/solidification technologies for mixed wastes. Grouting has been used to stabilize and solidify hazardous and low-level waste for decades. Vitrification has long been developed as a high-level-waste alternative and has been under development recently as an alternative treatment technology for low-level mixed waste. Laboratory testing has been performed to develop grout and vitrification formulas for mixed-waste sludges currently stored in underground tanks at Oak Ridge National Laboratory (ORNL) and to compare these waste forms.

Envelopes, or operating windows, for both grout and soda-lime-silica glass formulations for a surrogate sludge were developed. One formulation within each envelope was selected for testing the sensitivity of performance to variations $( \pm 10 \mathrm{wt} \%)$ in the waste form composition and variations in the surrogate sludge composition over the range previously characterized in the sludges. In addition, one sludge sample of an actual mixed-waste tank was obtained, a surrogate was developed for this sludge sample, and grout and glass samples were prepared and tested in the laboratory using both surrogate and the actual sludge. The sensitivity testing of a surrogate tank sludge in selected glass and grout formulations is discussed in this paper, along with the hot-cell testing of an actual tank sludge sample.

\section{Background}

Numerous glass families have been developed and evaluated on a commercial scale. Examples of these families include soda-lime-silicate, borosilicate, lead silicate, aluminosilicate, halide, borate, phosphate, sulfide, chalcogenide, chalcohalide, oxyhalide, oxynitride and oxycarbide glasses (EPA, 1992 and Varshneya, 1994). Only three of these families, however, have demonstrated a tolerance for high

*Managed by Lockheed Martin Energy Research Corp. under contract DE-AC05-96OR22464 with the U.S. Department of Energy. 
uranium concentration; and uranium is one of the principal constituents of the waste being studied. These three families-borosilicate, soda-lime-silica (SLS) and phosphate-became the three of interest. Phosphate glasses are known to be readily attacked by water (Varshneya, 1994) and, thus, were quickly discarded as a candidate for further study. Borosilicate glasses, which have been used extensively for immobilization of high-level radioactive wastes, have a large known immiscibility gap in the $\mathrm{CaO}-\mathrm{B}_{2} \mathrm{O}_{3}-\mathrm{SiO}_{2}$ system (Volf, 1984). High calcium content is a major concern for the present waste; consequently, the experimental study presented herein focused on the SLS system. The SLS system has been evaluated previously for numerous low-level radioactive and chemically hazardous (i.e., mixed) waste sludges (Jantzen et al., 1995).

A methodology for calculating the maximum composition range for formation of glass has been developed previously (Gilliam et al., 1996). The methodology is based upon Stevels' theory (Stevels, 1948,1954 , and 1960/61) in which he calculated the mean possible numbers of bridging oxygen per $\mathrm{SiO}_{2}$. A minimum of one bridging oxygen is necessary for a plausible glass structure to form. The predicted maximum acceptable composition ranges, shown in Fig. 1, are based upon the assumption that the waste is the source of either alkali or alkaline earth material in the formulations; that is, of the three components presented in the figure, the waste supplied one of the components and only two are added to the waste for any given formulation. The calculated composition ranges for glass formulations of potential interest are bounded by the lines A-A, B-B, and C-C. The recipes for further evaluation are those additives that, when combined with the waste, result in compositions within the bounded region.

Note that the line A-A, representing a minimum bridging oxygen of $\sim 1$, corresponds to a waste loading of approximately $50 \mathrm{wt} \%$ on an oxide basis. For this glass-forming system and surrogate compositions, therefore, a waste loading of $50 \mathrm{wt} \%$ (on an oxide basis) represents the maximum achievable waste loading.

Similarly, cementitious stabilizing and solidifying agents have been used for decades to treat hazardous and radioactive wastes (Conner, 1990; IAEA, 1993). Agents used in treating wastes include cements (including Portland cements and jet cements), lime, fly ash (both Class F and $\mathrm{C}$ ), ground, granulated blast-furnace slag, sodium silicate, various clays, and additives and reagents too numerous to list, including several proprietary reagents. The stabilizing capabilities of Indian Red Pottery Clay (IRPC) for ${ }^{137} \mathrm{Cs}$ and of cement-fly ash for ${ }^{90} \mathrm{Sr}$ have been well established over the last three decades at ORNL (McDaniel et al., 1984; Gilliam, 1986; Gilliam and Loflin, 1986; and Gilliam et al., 1987). In 


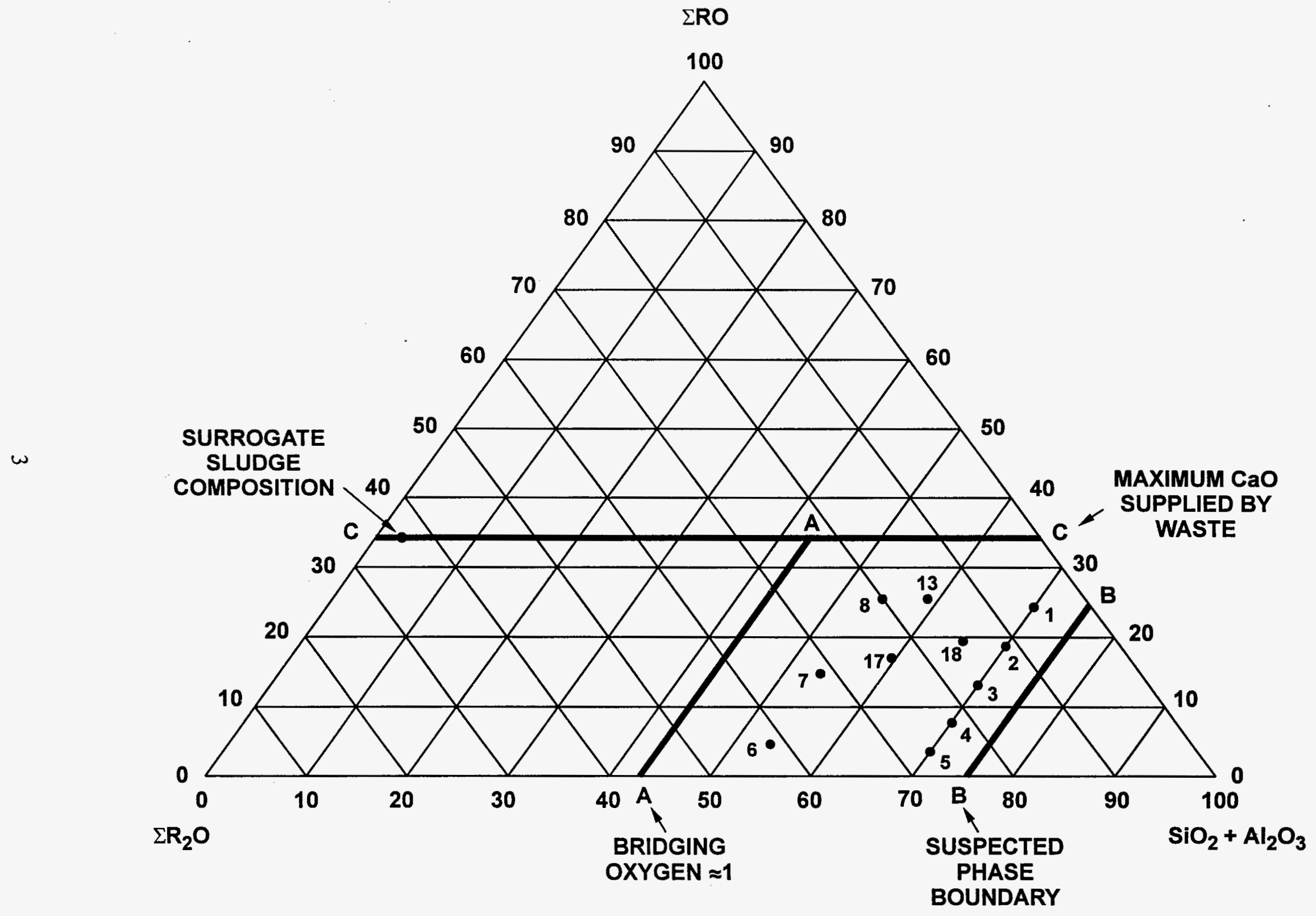

Fig. 1. Ternary diagram for the soda-lime-silica glass-making region. 
addition, ground, granulated blast-furnace slag has proven to have reducing capabilities (Spence et al., 1989) to stabilize chromates and has demonstrated excellent stabilization of mercury in previously unpublished work at ORNL. Bentonite, attapulgite, rice-hull ash, and perlite were tested in dry blends for their ability to help prevent free water formation, and perlite worked best for the grouts tested. Hence, the stabilizing/solidifying agents chosen for this work were the following: Portland cement; Class F fly ash; ground, granulated blast-furnace slag; perlite; and IRPC.

\section{Experimental}

\section{Surrogate Laboratory Sensitivity Studies}

Surrogate Preparation. The surrogate wet sludge was prepared from reagent-grade chemicals to the desired composition. The chemicals were allowed to hydrolyze by mixing with the recipe water at least overnight. This wet surrogate sludge was then either mixed into grouts or processed further for vitrification testing. For vitrification testing, the wet surrogate sludge was dried at $105^{\circ} \mathrm{C}$ to a constant weight (observed mass loss of $52.4 \mathrm{wt} \%$ for the standard surrogate). The dried surrogate material was broken up with a hammer, followed by ball milling for approximately $2 \mathrm{~h}$. This dried, size-reduced material was passed through a $4.75-\mathrm{mm}$ sieve. It is this dried, homogenized, and sieved material that became the surrogate waste feed for the vitrification studies. Homogenization of the dried material proved difficult because of the presence of a hard white crust on the upper surface of the dried waste. This white crust was determined to be $\mathrm{CaCO}_{3}$.

Grout Preparation and Testing. The dry blends mixed with the surrogate wet sludge to make grouts consisted of blends of two or more of the following dry powders: (1) ground, granulated blast furnace slag (slag) with a Blaine fineness of $6220 \mathrm{~cm}^{2} / \mathrm{g}$ from the Koch Minerals Co.; (2) Type I-II Portland cement (cement) from the Dixie Cement Co.; (3) Class F fly ash (fly ash) from the American Fly Ash Co.; (4) Grade H-200 perlite from the Harborlite Corp. (perlite); and (5) IRPC from the American Art Clay Co. The dry blends were blended for $2 \mathrm{~h}$ in an 8-qt twin-shell blender (or V-blender) from the Patterson-Kelley Co.

The grouts were mixed in a Model N-50 Hobart mixer using a wire whip. The surrogate wet sludge was added to the Hobart bowl first, then the dry blend was added to the sludge while mixing on low speed (30-60 s). The grout was then mixed on low speed for 2 min and medium speed for 2 min, cast into containers or molds for performance testing, and cured. The procedure for spiking with radionuclides for making leach samples consisted of adding the spike to the wet sludge in the Hobart 
bowl, mixing on low speed for $20 \mathrm{~min}$, then adding the dry blend using the above procedure. The freshly made grout was stored in a humidity cabinet and cured in a humid environment at $30 \pm 1^{\circ} \mathrm{C}$ for $28 \mathrm{~d}$ for the sensitivity testing.

The grout performance testing for the scope testing consisted of measuring the density, 28-d unconfined compressive strength, 28-d free water, 28-d toxicity characteristic leaching procedure (TCLP) performance, and the 28 -d leachability index of ${ }^{85} \mathrm{Sr}$ and ${ }^{137} \mathrm{Cs}$. The free water was measured by casting $250 \mathrm{~mL}$ of grout into a graduated cylinder and measuring the volume of free water standing over the solid grout. This property is reported as vol \%, calculated by dividing the observed free-water vol \% water volume in $\mathrm{mL}$ by $250 \mathrm{~mL}$ and multiplying by 100 . The density of the freshly mixed grout was obtained by measuring the net mass in $\mathrm{g}$ of the $250 \mathrm{~mL}$ of grout in the free-water test and dividing by 250 $\mathrm{mL}$ to obtain the density in units of $\mathrm{g} / \mathrm{mL}$. The density of the surrogate sludges was also obtained using the graduated cylinders. For the unconfined compressive strength, nominal 5.08-cm (2-in.) cubes of grout were cast and cured. After curing $28 \mathrm{~d}$, the cube dimensions were measured and the force $\left(\mathrm{lb}_{f}\right)$ required to crush the cube was measured on a Tinius-Olsen Machine. Dividing the crushing force by the cube cross-sectional area gave the unconfined compressive strength (psi).

For the leachability index, a semidynamic leach test was performed using a modification of the ANSI/ANS-16.1 test (American Nuclear Society, 1986). (In a semidynamic test, the samples remain quiescent in the leachate for a set time interval and are then moved to a fresh leachate at zero concentration for the next time interval.) The grout samples were leached in deionized water. The concentration of the radionuclides were measured by gamma spectroscopy, using a germanium detector with an efficiency of $10 \%$ and a background of 30 counts per $1,000 \mathrm{~s}$, or 0.03 counts per second (cps). After a 30 -s rinse, the leachates were changed at cumulative times of $1,2,3,4$, and $7 \mathrm{~d}$. The effective diffusion coefficient was estimated from the cumulative fraction leached with time, assuming diffusioncontrolled leaching. The leachability index is the negative of the logarithm of the effective diffusion coefficient.

Glass Preparation and Testing. The ingredients were weighed, combined and rolled in a ball mill for approximately $30 \mathrm{~min}$. The material was then placed in a $99.8 \%$ pure alpha- $\mathrm{Al}_{2} \mathrm{O}_{3}$ crucible with a loose-fitting lid. The crucible and contents were placed in a high-temperature furnace to achieve melting. The furnace was programmed to ramp to $1400^{\circ} \mathrm{C}$ at $300^{\circ} \mathrm{C} / \mathrm{h}$ and hold at the melt temperature for $4 \mathrm{~h}$. After this step, part of the fluid glass was poured into a graphite cylinárical mold and the remainder was poured into a stainless steel pan. After filling with the melted glass, the graphite molds 
were placed in a furnace at $535^{\circ} \mathrm{C}$ for $2 \mathrm{~h}$ and then allowed to cool to room temperature in the furnace to anneal the glass. The annealed glass cylinders were subjected to ANSI/ANS-16.1 leaching to measure the nonradioactive leachability index of cesium and strontium. The leachate concentrations were measured by inductively coupled plasma-mass spectroscopy (ICP-MS). The nonannealed glass poured into the stainless steel pan was submitted for TCLP analysis.

TCLP Testing. A modified TCLP test was performed on both the grout and glass samples from the laboratory sensitivity testing. The modified procedure extracts a $10-\mathrm{g}$ sample with $200 \mathrm{~mL}$ of extractant, rather than the standard $200-\mathrm{g}$ extraction with $2 \mathrm{~L}$ of extractant. The TCLP test uses one of two extractants: (1) an acetic acid solution with sodium hydroxide added (TCLP Extraction Fluid No. 1, $\mathrm{pH}$ of about 4.9); or (2) the full-strength acetic acid solution (TCLP Extraction Fluid No. 2, $\mathrm{pH}$ of about 2.9). (The procedure dictates which extractant to use based on the buffering capability of the sample when mixed with a hydrochloric acid solution.) After extracting $18 \mathrm{~h}$, the undissolved solids are filtered from the extract and the extract is digested using a microwave digester. The concentration of the inorganic RCRA metals in the extract were then measured using a Thermo Jarrel Ash ICAP 61E Trace Analyzer (ICP). Although selenium and arsenic analyses by ICP are not usually accepted, EPA accepts the higher sensitivity of the 61E. The concentration of mercury in the TCLP extract was measured using a Leeman Labs PS 200 cold vapor atomic absorption (CVAA) mercury analyzer. Some of the hot- cell samples were also tested with this dedicated laboratory equipment, but the samples with high gamma fields from the hot sample were submitted to an analytical laboratory with hot cells for characterization of such samples.

\section{Hot-Cell Studies}

Grout Preparation and Testing. Standard equipment typically used for the preparation of cement-based grouts had to be modified for use with manipulators within the confines of the hot cell. Using the modified equipment, grout was prepared within the confines of the hot cell, using essentially the same preparation procedures and the standard grout formulation used in the laboratory sensitivity testing of the weighted average surrogate. Grouts were made and tested from the actual tank sludge sample and its surrogate. The sludge water content was adjusted to $80 \mathrm{wt} \%$, the water content required for processability, as indicated in laboratory testing of the actual sample surrogate. Hot-cell grout curing was done by sealing the grout samples under humid conditions at the hot-cell temperature $\left(\approx 27-29^{\circ} \mathrm{C}\right)$. Performance testing consisted of measurements of density, free water, penetration resistance, and TCLP 
testing. The density, free water, and TCLP testing were conducted in the same manner as in the laboratory sensitivity testing, except for the use of a hot-cell analytical laboratory for the high-gamma field (TCLP) samples.

For penetration resistance, a penetrometer with a wire penetrator tip of $1 / 40 \mathrm{in}^{2}$ was used to follow the rate of set. The penetrometer apparatus was operated by pulling down on a handle that was set such that its movement into the sample was the same each time. On the dial display above, pounds force was displayed by a marker dial that moved one way with the dial. Penetration resistance, and therefore rate of set, could be related to the area of the penetrator surface so that penetration resistance could be calculated by multiplying the dial value by 40 to obtain this value in units of pound-per-square-inch ( psi). The handle of the apparatus was modified with a swivel for the manipulator hand to allow movement forward in the confines of the cell. Forms to contain the cured grout were fabricated from 2in. PVC pipe caps epoxied to a piece of wood such that the surface of the tops were parallel with the base. Penetrometer readings were obtained at $24,48,72,96$ and $168 \mathrm{~h}$, or $7 \mathrm{~d}$.

Glass Preparation and Testing. For both the surrogate sludge and the actual sludge, the sludges were weighed into new, 90-cc platinum crucibles, and precipitated silica and finely powdered limestone were blended to the desired homogeneity based upon color, using a spatula with manipulator grips attached. The glass formulation used in the laboratory sensitivity testing was further refined at Savannah River Technology Center (SRTC) to allow a lower furnace temperature $\left(1300^{\circ} \mathrm{C}\right)$.

The two glasses made with the actual tank sludge sample and its surrogate were prepared in the same manner; that is, the well-mixed contents of the platinum crucible were set into a clay crucible inside the furnace to receive any overflow caused by potential foaming and to prevent the possible corrosion of the oven refractory. The oven was started at ambient temperature in the cell $\left(27-29^{\circ} \mathrm{C}\right)$. The crucible inside and the furnace were programmed to ramp at $15^{\circ} \mathrm{C} / \mathrm{min}$ to $1300^{\circ} \mathrm{C}$ and then hold this temperature for a minimum of $4 \mathrm{~h}$. The dry solid, surrogate blend used to prepare this glass was well blended, so the hold time was $4 \mathrm{~h}$. However, with the glass formed from actual waste, limestone and precipitated silica, the hold time was $4.75 \mathrm{~h}$ because blending these glass- forming additives with a spatula in the platinum crucible for nearly $1 \mathrm{~h}$ by the technician still may not have made as homogeneous a blend as desired. Consequently, the melt time was extended to allow more time for thermal mixing to take place.

Once removed, the glasses were handled in accordance with the Product Consistency Test (PCT) procedure (Jantzen et al., 1992). Implementing this procedure also required modification of equipment 
necessary to pulverize, to screen to the proper mesh size, and to wash and separate the glasses without cross-contamination. A small pulverizer using tungsten carbide blades was mated to a support stand that cradled it. An attached handle with a swivel permitted the manipulator hand to tilt the whole pulverizer forward with its contents of ground glass. The pulverizer, once tilted, emptied onto a series of screens with a catch pan that was placed on a laboratory jack stand used to adjust to the desired height. For pieces of glass that were thought to be too large, small chunks were placed inside a stainless steel cylinder welded to a based stand. A heavy steel tube slid inside this tube and was used as a hammer to break the glass. The base tube receiver containing the size-reduced glass was equipped with manipulator grips and, as such, could be lifted and poured directly into the top of the pulverizer.

The removal of screen fractions without losses of valuable product or contamination of the cell required that a means for removing the glass fractions be devised. The same stainless steel funnel designed for the placement of grout slurry into cylinders was employed to remove the glass. This funnel was washed with nitric acid and water and set aside for this use.

The funnel was sized such that its diameter allowed it to just fit inside the top 8-in. screen with the catch pan on the other side. The funnel was turned upside down and placed such that its 1-in. discharge was facing upward when inserted into the screen. A small plastic screw-on receiver bottle was then attached to this threaded discharge pipe. Because the funnel was equipped with manipulator grips on opposite sides, it could be picked up; the contents of the screen were tapped, allowing the glass fraction to flow into the receiver bottle below. This technique was repeated as necessary, with cleaning and drying steps in between uses.

Properly screened and washed glass was eventually charged into precleaned Parr leaching bombs for use in the PCT test. The details of the complete test are in the reference and will not be described here (Jantzen et al., 1992). The bombs received approximately $1.6 \mathrm{~g}$ of glass each, and the tops were torqued to $40 \mathrm{ft}-\mathrm{lb}$, the maximum value recommended by the manufacturer. This procedure was done so that all leach vessels were tightened the same amount.

\section{Results and Discussion}

\section{Laboratory Sensitivity Testing of Surrogate Sludge}

Sensitivity testing is the evaluation of the sensitivity of a selected formulation to changes in waste composition and changes in concentration of the final waste form composition. A surrogate wet 
sludge was developed for this study based on the weighted average sludge composition for the tank group from past characterization data (Sears et al., 1990). The composition for this surrogate is listed as the standard surrogate in Table 1. The TCLP performance of both the wet (used for grout feed) and dried (used for glass feed) standard surrogate sludge is listed in Table 2. The standard surrogate was characteristically hazardous for mercury (both wet and dry), cadmium (dry only), and chromium (dry only). In addition, both standard grout and glass formulations were tested with the surrogate composition containing the minimum water and maximum bad actors [maximum concentrations of Resource Conservation and Recovery Act (RCRA) metals, sulfate, and halides]. The standard grout formulation was also tested with the maximum water content reported in Sears et al., 1990. (Sludgewater content for glass was moot because its feed was based on dried sludge.) This procedures tested the standard formulations for variation in waste composition within the range of measured tank sludge variation. The radioactivity in the tank sludges comes primarily from ${ }^{137} \mathrm{Cs}$ and ${ }^{90} \mathrm{Sr}$, although neither is a major constituent of the tank sludges on a mass basis. The leachability indexes for these two radioisotopes were measured, or estimated, for both grout and glass. For grout, small, selected batches were spiked with ${ }^{137} \mathrm{Cs}$ and ${ }^{85} \mathrm{Sr}$ (substituted for ${ }^{90} \mathrm{Sr}$ because it is a gamma emitter and allowed leachate analysis by gamma spectroscopy) and leach testing was performed on the cured samples. For glạss, nonradioactive cesium and strontium salts were included in the glass feed, because of the potential for ${ }^{137} \mathrm{Cs}$ concentrations in the resulting product glasses was measured by total dissolution analysis. The concentrations in the leachates and extracts were measured by ICP-MS.

Grout. The dry-blend composition selected for sensitivity testing was as follows: 33, 20, 19, 20, and $20 \mathrm{wt} \%$ of slag, cement, fly ash, perlite, and IRPC, respectively. This dry blend was limited to a wet sludge loading of $55 \mathrm{wt} \%$, to ensure no free water. The standard grout composition is listed as Grout No. 1 in Table 3. In addition, Table 3 lists the four grouts selected for sensitivity testing of variation in the grout composition, taken from the $\pm 10 \%$ variation in the formulation. The sensitivity testing consisted of measuring the performance of the grouts listed in Table 3 using the standard surrogate sludge. In addition, the standard grouts (Grout No. 1) were also tested using the other two surrogates listed in Table 1 to measure the sensitivity over the range of surrogate compositions.

Tables 4 and 5 list the results for the sensitivity testing of the grouts: grout density, ratio of grout volume to sludge volume, free water, unconfined compressive strength, cesium and strontium leachability indexes and TCLP performance. 


\begin{tabular}{|c|c|c|c|}
\hline Compound & $\begin{array}{l}\text { Standard surrogate for the } \\
\text { tank set weighted average } \\
\text { (wt \%) }\end{array}$ & $\begin{array}{c}\text { Surrogate with the } \\
\text { maximum water of the tank } \\
\text { set } \\
\text { (wt \%) }\end{array}$ & $\begin{array}{l}\text { Surrogate with the } \\
\text { minimum water and } \\
\text { maximum bad actors of the } \\
\text { tank Set } \\
(\mathrm{wt} \%)\end{array}$ \\
\hline \multicolumn{4}{|c|}{ RCRA metals } \\
\hline $\mathrm{Ag}_{2} \mathrm{O}$ & $0.0019 \%$ & $0.0014 \%$ & $0.0054 \%$ \\
\hline $\mathrm{CdO}$ & $0.0023 \%$ & $0.0018 \%$ & $0.0048 \%$ \\
\hline $\mathrm{Na}_{2} \mathrm{Cr}_{2} \mathrm{O}_{7}$ & $0.0255 \%$ & $0.0193 \%$ & $0.0479 \%$ \\
\hline $\mathrm{HgCl}_{2}$ & $0.0040 \%$ & $0.0030 \%$ & $0.0080 \%$ \\
\hline $\mathrm{PbO}$ & $0.0296 \%$ & $0.0224 \%$ & $0.0506 \%$ \\
\hline $\mathrm{SeO}_{2}$ & $0.0066 \%$ & $0.0050 \%$ & $0.0078 \%$ \\
\hline $\mathrm{TINO}_{3}$ & $0.0021 \%$ & $0.0016 \%$ & $0.0026 \%$ \\
\hline \multicolumn{4}{|c|}{ Process metals } \\
\hline $\mathrm{Al}(\mathrm{OH})_{3}$ & $0.99 \%$ & $0.75 \%$ & $1.10 \%$ \\
\hline $\mathrm{CaCO}_{3}$ & $6.65 \%$ & $5.04 \%$ & $13.73 \%$ \\
\hline $\mathrm{Ca}(\mathrm{OH})_{2}$ & $2.21 \%$ & $1.68 \%$ & $2.47 \%$ \\
\hline $\mathrm{Fe}_{2} \mathrm{O}_{3}$ & $0.20 \%$ & $0.15 \%$ & $0.22 \%$ \\
\hline $\mathrm{KNO}_{3}$ & $3.78 \%$ & $2.87 \%$ & $4.23 \%$ \\
\hline $\mathrm{MgCO}_{3}$ & $0.33 \%$ & $0.25 \%$ & $0.37 \%$ \\
\hline $\mathrm{Mg}(\mathrm{OH})_{2}$ & $1.82 \%$ & $1.38 \%$ & $2.03 \%$ \\
\hline $\mathrm{NaNO}_{3}$ & $27.87 \%$ & $21.13 \%$ & $18.87 \%$ \\
\hline $\mathrm{NaCl}$ & $0.43 \%$ & $0.33 \%$ & $0.63 \%$ \\
\hline $\mathrm{NaF}$ & $0.14 \%$ & $0.11 \%$ & $0.18 \%$ \\
\hline $\mathrm{Na}_{2} \mathrm{SO}_{4}$ & $0.27 \%$ & $0.21 \%$ & $0.58 \%$ \\
\hline $\mathrm{Sr}\left(\mathrm{NO}_{3}\right)_{2}$ & $0.04 \%$ & $0.03 \%$ & $0.04 \%$ \\
\hline $\mathrm{Th}\left(\mathrm{NO}_{3}\right)_{4} \cdot 4 \mathrm{H}_{2} \mathrm{O}$ & $1.41 \%$ & $1.07 \%$ & $3.26 \%$ \\
\hline $\mathrm{UO}_{2}\left(\mathrm{NO}_{3}\right)_{2} \cdot 6 \mathrm{H}_{2} \mathrm{O}$ & $2.44 \%$ & $1.85 \%$ & $6.55 \%$ \\
\hline Total solids & $48.66 \%$ & $36.90 \%$ & $54.40 \%$ \\
\hline Water & $51.34 \%$ & $63.10 \%$ & $45.60 \%$ \\
\hline Sludge & $100.00 \%$ & $100.00 \%$ & $100.00 \%$ \\
\hline
\end{tabular}


Table 2. Concentrations of the RCRA metals and uranium in the TCLP extract of the surrogate sludge

\begin{tabular}{|c|c|c|c|c|c|}
\hline \multirow{2}{*}{ Analyte } & \multicolumn{5}{|c|}{ TCLP Extract Concentration (mg/L) } \\
\hline & $\begin{array}{l}\text { Wet sludge } \\
\text { sample }\end{array}$ & $\begin{array}{c}\text { Dried sludge } \\
\text { sample }\end{array}$ & UTS limits ${ }^{a}$ & $\begin{array}{c}\text { RCRA } \\
\text { characteristic } \\
\text { limits }^{b}\end{array}$ & $\begin{array}{c}\text { TCLP LDR } \\
\text { limits }^{c}\end{array}$ \\
\hline $\mathrm{Cd}$ & 0.904 & 1.106 & 0.190 & 1.000 & 1.000 \\
\hline $\mathrm{Cr}$ & 2.69 & 5.95 & 0.86 & 5.00 & 5.00 \\
\hline $\mathrm{Hg}$ & 1.54 & $\mathrm{NM}^{\mathrm{d}}$ & 0.025 & 0.200 & 0.200 \\
\hline $\mathrm{Pb}$ & 0.111 & 0.919 & 0.370 & 5.000 & 5.000 \\
\hline $\mathrm{Se}$ & 0.118 & 0.244 & 0.160 & 1.000 & 5.700 \\
\hline $\mathrm{Tl}$ & 0.486 & 1.206 & 0.078 & $\mathrm{~N} / \mathrm{A}$ & $\mathrm{N} / \mathrm{A}$ \\
\hline $\mathrm{U}$ & 511 & 943 & N/A & $\mathrm{N} / \mathrm{A}$ & N/A \\
\hline TCLP Fluid No. & 2 & 2 & & & \\
\hline $\mathrm{pH}$ after extraction & 6.75 & 7.46 & & & \\
\hline
\end{tabular}

"The Universal Treatment Standard (UTS) limits for the TCLP extract concentration.

${ }^{b}$ Toxicity limits for TCLP extract concentrations in determining whether a waste is characteristically hazardous by the RCRA.

- The TCLP extract concentration limits by the Land Disposal Restrictions (LDR) of RCRA.

"Not measured, because the mercury compound was not included in this sample. It was assumed that mercury would volatilizc during vitrification and, therefore, was not included in the surrogate vitrified.

\begin{tabular}{|c|c|c|c|c|c|}
\hline Grout component & $\begin{array}{c}\text { Grout No. } 1 \\
\text { (standard) } \\
(\text { wt } \%)\end{array}$ & $\begin{array}{c}\text { Grout No. } 2 \\
\text { (wt \%) }\end{array}$ & $\begin{array}{c}\text { Grout No. } 3 \\
\text { (wt \%) }\end{array}$ & $\begin{array}{c}\text { Grout No. } 4 \\
\text { (wt \%) }\end{array}$ & $\begin{array}{c}\text { Grout No. } 5 \\
\text { (wt \%) }\end{array}$ \\
\hline IRPC & $3.6 \%$ & $3.2 \%$ & $4.0 \%$ & $3.8 \%$ & $3.4 \%$ \\
\hline Pcrlite & $9.0 \%$ & $8.0 \%$ & $10.0 \%$ & $9.4 \%$ & $8.5 \%$ \\
\hline Fly Ash & $8.6 \%$ & $7.6 \%$ & $9.5 \%$ & $8.9 \%$ & $8.1 \%$ \\
\hline Slag & $14.9 \%$ & $13.2 \%$ & $16.5 \%$ & $12.7 \%$ & $17.2 \%$ \\
\hline Cement & $9.0 \%$ & $8.0 \%$ & $10.0 \%$ & $7.7 \%$ & $10.4 \%$ \\
\hline Wet Sludge & $55.0 \%$ & $59.9 \%$ & $50.0 \%$ & $57.5 \%$ & $52.2 \%$ \\
\hline Total & $100.0 \%$ & $100.0 \%$ & $100.0 \%$ & $100.0 \%$ & $100.0 \%$ \\
\hline $\mathrm{W} / \mathrm{S}^{\mathrm{a}}$ & $0.40^{b}$ & 0.45 & 0.35 & 0.43 & 0.37 \\
\hline
\end{tabular}

"Water/solids ratio for the standard surrogate sludge.

${ }^{b} \mathrm{~W} / \mathrm{S}=0.40$ with the standard surrogate; $\mathrm{W} / \mathrm{S}=0.53$ for the surrogate sludge with the maximum water; $\mathrm{W} / \mathrm{S}=0.33$ for the surrogate sludge with the minimum water and maximum bad actors. 


\begin{tabular}{|c|c|c|c|c|c|c|c|}
\hline \multirow[b]{2}{*}{$\begin{array}{l}\text { Surrogate } \\
\text { sludge }\end{array}$} & \multirow[b]{2}{*}{ Grout No. } & \multirow[b]{2}{*}{$\begin{array}{l}\text { Grout density } \\
\qquad(\mathrm{g} / \mathrm{mL})\end{array}$} & \multirow{2}{*}{$\begin{array}{l}\text { Volume ratio } \\
\text { of grout to wet } \\
\text { sludge }\end{array}$} & \multirow{2}{*}{$\begin{array}{c}28-d \text { free } \\
\text { water (vol \%) }\end{array}$} & \multirow{2}{*}{$\begin{array}{c}28-d \\
\text { Unconfined } \\
\text { compressive } \\
\text { strength (psi) }\end{array}$} & \multicolumn{2}{|c|}{$\begin{array}{l}\text { Leachability } \\
\text { index }\end{array}$} \\
\hline & & & & & & ${ }^{85} \mathrm{Sr}$ & ${ }^{137} \mathrm{Cs}$ \\
\hline \multirow{5}{*}{$\begin{array}{l}\text { Standard } \\
\text { Sludge }\end{array}$} & 1 & 1.76 & 1.44 & 0.0 & 1663 & 9.5 & 9.9 \\
\hline & 2 & 1.72 & 1.36 & 0.0 & 776 & 9.4 & 9.7 \\
\hline & 3 & 1.78 & 1.57 & 0.0 & 1679 & 10.0 & 10.5 \\
\hline & 4 & 1.75 & 1.39 & 0.0 & 1781 & 9.4 & 9.9 \\
\hline & 5 & 1.82 & 1.47 & 0.0 & 2086 & 9.9 & 10.1 \\
\hline $\begin{array}{c}\text { Minimum } \\
\text { water + } \\
\text { maximum bad } \\
\text { actors }\end{array}$ & 1 & 1.64 & 1.55 & 0.0 & 1339 & 9.2 & 9.3 \\
\hline $\begin{array}{l}\text { Maximum } \\
\text { water }\end{array}$ & 1 & 1.82 & 1.39 & 0.0 & 1810 & 9.6 & 10.5 \\
\hline
\end{tabular}

\begin{tabular}{|c|c|c|c|c|c|c|c|c|c|c|}
\hline \multirow{2}{*}{$\begin{array}{l}\text { Surrogate } \\
\text { sludge }\end{array}$} & \multirow{2}{*}{$\begin{array}{l}\text { Grout } \\
\text { No. }\end{array}$} & \multicolumn{7}{|c|}{$\begin{array}{l}\text { TCLP extract concentration } \\
(\mathrm{mg} / \mathrm{L})\end{array}$} & \multirow{2}{*}{$\begin{array}{l}\text { TCLP } \\
\text { fluid No. }\end{array}$} & \multirow{2}{*}{$\mathrm{pH}$} \\
\hline & & $\mathrm{Cd}$ & $\mathrm{Cr}$ & $\mathrm{Hg}^{\prime \prime}$ & $\mathrm{Pb}$ & $\mathrm{Se}$ & $\mathrm{Tl}$ & $\mathrm{U}$ & & \\
\hline \multirow{5}{*}{$\begin{array}{l}\text { Standard } \\
\text { sludge }\end{array}$} & 1 & $<0.002$ & 0.014 & 0.0002 & 0.009 & 0.053 & $<0.006$ & 0.071 & 1 & 10.23 \\
\hline & 2 & $<0.002$ & 0.013 & 0.0003 & 0.016 & 0.028 & $<0.006$ & $<0.039$ & 1 & 10.50 \\
\hline & 3 & $<0.002$ & 0.011 & 0.0004 & 0.009 & 0.041 & $<0.006$ & $<0.039$ & 1 & 10.29 \\
\hline & 4 & $<0.002$ & 0.014 & 0.0004 & 0.008 & 0.130 & $<0.006$ & $<0.039$ & 1 & 10.36 \\
\hline & 5 & $<0.002$ & 0.010 & 0.0003 & 0.008 & 0.083 & $<0.006$ & $<0.039$ & 1 & 10.41 \\
\hline $\begin{array}{c}\text { Min. } \\
\text { watcr + } \\
\text { max. bad } \\
\text { actors }\end{array}$ & 1 & $<0.002$ & 0.022 & 0.0001 & 0.009 & 0.034 & $<0.006$ & $<0.039$ & 1 & 10.43 \\
\hline $\begin{array}{l}\text { Max. } \\
\text { water }\end{array}$ & 1 & $<0.002$ & 0.038 & 0.0002 & 0.012 & 0.019 & $<0.006$ & 0.103 & 1 & 10.51 \\
\hline \multicolumn{11}{|c|}{ TCLP UTS } \\
\hline & & 0.190 & 0.860 & 0.025 & 0.370 & 0.160 & 0.078 & N/A & & \\
\hline
\end{tabular}

"Measured by cold vapor atomic absorption; all other extract concentrations were measured by ICP.

"The Universal Treatment Standard (UTS) limits for the TCLP extract concentration. 
The selected standard grout had a volume increase of $44 \%$, no free water, an average compressive strength of 1,663 psi, an acceptable TCLP performance, and cesium and strontium leachability indexes $>9$. The variation in grout and surrogate composition made the volume increase vary from 36 to $55 \%$. Although the composition variations affected the appearance of free water during the curing process and the rate at which the free water disappeared, none of the composition variations had any free water after curing $28 \mathrm{~d}$. The composition variations affected significantly the compressive strength, ranging from 776 to $2,086 \mathrm{psi}$, but all were significantly $>500$ psi (the recommended NRC criteria for solidified lowlevel radioactive waste). The composition variations had little effect on the TCLP performance or leachability indexes. All TCLP extract concentrations were below the limiting values for RCRA regulations for characteristically hazardous waste, TCLP Land Disposal Restrictions, or Universal Treatment Standards. All leachability indexes were well above the NRC recommended minimum value of 6.0 .

Unfortunately, this standard grout was difficult to process and handle, because of its apparent dryness from the water sorption of the perlite and clay and hydration of the binders. This dry blend may volatilization, which was not permitted in the laboratory vitrification facility. The cesium and strontium would be able to handle wet sludge loadings higher than $55 \mathrm{wt} \%$, without bleed water at $28 \mathrm{~d}$, and the extra water would assist in processing. Field operation with this fairly "dry" grout may require some water addition, depending on the mixing and handling equipment and the water content of the sludge being processed.

Glass. The envelope of potential soda-lime-silica compositions is illustrated in Fig. 1. The present studies have identified a potential problem in the glass formulas, with the highest waste loadings producing melts with glass adhering to the crucible wall above the melt line. The appearance of glass on the crucible walls is of concern because of its potential impact on actual field-scale melter operations. In essence, the glass is of low viscosity and can penetrate into the microcracks of the melter liner. This fluid melt is highly corrosive and can accelerate liner corrosion by this penetration. Consequently, it can significantly reduce the life-time of a melter liner, thereby increasing cost and reducing operating time; in the worst case, fluid melt can present a safety hazard by corroding through the melter and allowing molten glass to flow out into the working environment. Unfortunately, there is little, if any, data on the increased rate of corrosion induced by this phenomenon.

It is believed that the causes of this phenomenon are oxidizing conditions in the glass melt and production of excessive amounts of off-gas. It is further believed that this phenomenon can be 
overcome, thereby making the majority of the predicted acceptable composition regime available (or acceptable) during actual operations. However, discussions of this phenomenon and its resolution are beyond the scope of this paper. For the purposes of the sensitivity tests reported herein, a recipe for sensitivity testing had to be selected from a much smaller region than that predicted in Fig. 1. Thus, the formulation for additional testing was chosen from the composition regime bounded by formulations V-1, V-3, V-17 and V-13, as illustrated in Fig. 1; and was arbitrarily taken to be the composition at the center of this region (i.e., V-18). Thus, the selected "standard" recipe was not optimized, and later refinements increased the waste loading and decreased the furnace temperature for the hot-cell tests. (Decreased furnace temperature should reduce cesium volatilization.)

Table 6 lists the feed compositions and the ternary glass compositions for the sensitivity test glasses. The standard glass was tested in triplicate (V-18, V-24, and V-25). Four variations of the $\pm 10 \%$ variations in the feed mix were picked for sensitivity testing (V-19 through V-22). The remaining glass (V-23) used the standard glass recipe, but extra RCRA metal compounds were added to the dried sludge to simulate the maximum RCRA metals listed in the tank characterization data. The solids composition of the standard surrogate sludge listed in Table 1 was used for seven of the eight glasses, and the

\begin{tabular}{|c|c|c|c|c|c|c|}
\hline \multirow{2}{*}{$\begin{array}{c}\text { Vitrification } \\
\text { No. }\end{array}$} & \multicolumn{3}{|c|}{ Fced mix (wt \%) } & \multicolumn{3}{|c|}{ Ternary glass compositions (wt \%) } \\
\hline & $\mathrm{CaCO}_{3}$ & $\begin{array}{c}\text { Spiked dried } \\
\text { waste }\end{array}$ & $\mathrm{SiO}_{2}$ & $\begin{array}{c}\text { Alkaline } \\
\text { oxides } \\
\end{array}$ & Alkali oxides & $\begin{array}{c}\text { Glass former } \\
\text { oxides } \\
\end{array}$ \\
\hline $18^{\prime \prime}$ & $14.3 \%$ & $41.0 \%$ & $44.7 \%$ & $19.8 \%$ & $15.2 \%$ & $65.0 \%$ \\
\hline $19^{h}$ & $13.1 \%$ & $45.9 \%$ & $41.0 \%$ & $20.6 \%$ & $17.6 \%$ & $61.8 \%$ \\
\hline $20^{\prime \prime}$ & $15.4 \%$ & $36.3 \%$ & $48.3 \%$ & $19.2 \%$ & $13.0 \%$ & $67.8 \%$ \\
\hline $21^{\prime \prime}$ & $15.5 \%$ & $44.6 \%$ & $39.8 \%$ & $22.4 \%$ & $17.2 \%$ & $60.4 \%$ \\
\hline $22^{h}$ & $13.0 \%$ & $37.3 \%$ & $49.7 \%$ & $17.4 \%$ & $13.3 \%$ & $69.3 \%$ \\
\hline $23^{r}$ & $14.3 \%$ & $41.0 \%$ & $44.7 \%$ & $19.8 \%$ & $15.2 \%$ & $65.0 \%$ \\
\hline $24^{d}$ & $14.3 \%$ & $.41 .0 \%$ & $44.7 \%$ & $19.8 \%$ & $15.2 \%$ & $65.0 \%$ \\
\hline $25^{d}$ & $14.3 \%$ & $41.0 \%$ & $44.7 \%$ & $19.8 \%$ & $15.2 \%$ & $65.0 \%$ \\
\hline
\end{tabular}


surrogate solids composition with maximum RCRA metals listed in Table 1 was used for V-23. These eight glass melts poured readily into graphite molds, resulting in clear glass cylinders for leach test. The cylinders were tinted slightly green or amber with a cluster of gas bubbles trapped in the center. The cylinders were slightly rounded at the top as a result of the glass melt meniscus formed when the mold was filled with the viscous glass. The dimensions and masses of the cylinders were measured and used to calculate the estimated glass densities listed in Table 7. Because the cylinders were not perfect right cylinders and contained gas bubbles, the densities listed in Table 7 are estimated bulk densities. These bulk glass densities were used with the estimated volume of wet sludge used in making these glass cylinders and the cylinder masses and to calculate the ratios of the resulting glass volume to the original wet-sludge volume. These values imply that one can expect a volume reduction by more than a factor of 2 upon vitrifying the wet sludge into SLS glass (not counting any off-gas or secondary waste volumes), compared with the volume increase of about $50 \mathrm{vol} \%$, if grouted.

\begin{tabular}{|c|c|c|}
\hline $\begin{array}{c}\text { Glass leach sample } \\
\text { vitrification No. }\end{array}$ & $\begin{array}{c}\text { Calculated bulk } \\
\text { density " } \\
(\mathrm{g} / \mathrm{cc})\end{array}$ & $\begin{array}{c}\text { Calculated volume } \\
\text { ratio of glass/wet } \\
\text { sludge } \\
(\text { vol } \%)\end{array}$ \\
\hline 18 & 2.80 & $42 \%$ \\
\hline 19 & 2.45 & $43 \%$ \\
\hline 20 & 2.50 & $54 \%$ \\
\hline 21 & 2.58 & $42 \%$ \\
\hline 22 & 2.57 & $50 \%$ \\
\hline 23 & 2.54 & $47 \%$ \\
\hline 24 & 2.51 & $47 \%$ \\
\hline 25 & 2.57 & $46 \%$ \\
\hline
\end{tabular}

"Bulk density calculated for leach samples, assuming perfect right cylinders. With the slightly rounded tops, this includes some air volume at the top in addition to the gas bubbles trapped inside the glass. 
These glass cylinders were leached in deionized water at room temperature. Daily monitoring of the cesium and strontium concentration of one leachate indicated that no measurable concentrations accumulated during the first week. After $6.85 \mathrm{~d}$, the leachates were replaced with fresh deionized water and the cesium and strontium concentrations were measured in these first leachates. Table 8 lists these leachate concentrations along with the cesium and strontium concentration measured in each glass by total dissolution analysis, as well their recovery. Some volatilization of cesium was expected, and the results indicate a presence of at least 44 to $57 \mathrm{wt} \%$ of the original cesium in the glass product. However, the sample dissolution might not have dissolved all the solids. This hypothesis appeared to conform with the lower-than-expected recovery for strontium. The $122 \%$ recovery for V-21 also suggests the possibility of heterogeneity in the glass, or an error in spiking (the higher strontium leachate concentration for V-21 is consistent with a higher concentration actually present in this glass sample).

Table 8. Total dissolution analysis of glasses from sensitivity testing and leachate analysis with estimated leachability indexes for cesium and strontium.

\begin{tabular}{|c|c|c|c|c|c|c|c|c|}
\hline \multirow{2}{*}{$\begin{array}{l}\text { Vitrification } \\
\text { No. }\end{array}$} & \multicolumn{2}{|c|}{$\begin{array}{c}\text { Total dissolution } \\
\text { analysis } \\
(\mathrm{mg} / \mathrm{kg})\end{array}$} & \multicolumn{2}{|c|}{$\%$ Recovered $"$} & \multicolumn{2}{|c|}{$\begin{array}{c}\text { Leachate concentration }^{b} \\
(\mu \mathrm{g} / \mathrm{L})\end{array}$} & \multicolumn{2}{|c|}{ Leachability index } \\
\hline & $\mathrm{Sr}$ & Cs & $\mathrm{Sr}$ & Cs & $\mathrm{Sr}$ & Cs & $\mathrm{Sr}$ & Cs \\
\hline 18 & 1,100 & 1,027 & $80 \%$ & $44 \%$ & 0.167 & $<0.050$ & 18.4 & $>19.4$ \\
\hline 19 & 1,218 & 1,278 & $88 \%$ & $55 \%$ & 0.310 & $<0.050$ & 17.8 & $>19.5$ \\
\hline 20 & $1,07 !$ & 1,324 & $78 \%$ & $57 \%$ & $<0.040$ & $<0.050$ & $>19.5$ & $>19.5$ \\
\hline 21 & 1,687 & 1,009 & $122 \%$ & $44 \%$ & 0.680 & $0.039^{d}$ & 17.5 & 19.5 \\
\hline 22 & 1,013 & 1,319 & $73 \%$ & $57 \%$ & 0.116 & $<0.050$ & 18.6 & $>19.5$ \\
\hline 23 & 1,073 & 1,316 & $78 \%$ & $57 \%$ & 0.188 & $0.030^{\mathrm{d}}$ & 18.2 & 20.0 \\
\hline 24 & 1,062 & 1,312 & $77 \%$ & $57 \%$ & 0.416 & $0.023^{\mathrm{d}}$ & 17.5 & 20.2 \\
\hline 25 & 948 & 1,145 & $69 \%$ & $50 \%$ & 0.231 & $0.015^{\mathrm{d}}$ & 17.9 & 20.5 \\
\hline
\end{tabular}

"The dried sludge was spiked with enough strontium nitrate and cesium acetate to give each glass concentrations of 1,380 and $2,308 \mathrm{mg} / \mathrm{kg}$, of strontium and cesium, respectively. Some cesium volatilization was expected, but incomplete dissolution or heterogeneous distribution can also account for the observed differences.

"One leachate concentration, monitored daily, remained below detection limits for cesium and strontium. The samples were removed from the deionized water leachant after $6.85 \mathrm{~d}$, and the listed leachate concentrations were measured by ICP-MS.

'The listed leachability indexes were calculated from the listed single leachate analysis after leaching $6.85 \mathrm{~d}$, assuming diffusion-controlled dynamic leaching, that is, zero leachate concentration.

A A small concentration was detected, but was below the quantization limit of $0.050 \mu \mathrm{g} / \mathrm{L}$, so the reported value is an estimate only. No concentration was detected for the reported < values, so < the quantization limit was reported for these values. 
Assuming the total dissolution analysis results are representative of the glass composition, one can expect that at least about $50 \mathrm{wt} \%$ of the cesium will remain with the glass in operations similar to the laboratory crucible melting.

These glass samples proved quite leach resistant, as illustrated by the low leachate concentrations listed in Table 8 and the low TCLP extract concentrations listed in Table 9. As with grout, the TCLP extract concentrations were well below UTS limits. Presumably, mercury would volatilize and have to be stabilized in the vitrification secondary wastes. Table 8 lists the leachability indexes estimated for cesium and strontium from the single leachate analyses, assuming diffusioncontrolled leaching with zero leachate concentration. Further analyses of the leachates indicated the silicon concentrations were $<0.02 \mathrm{mg} / \mathrm{L}$, well below the solubility limit for silica at room temperature in a neutral $\mathrm{pH}$; meaning that the leaching was not hampered by solubility limits of the glass matrix and that diffusion control with zero leachate concentration over the leach interval of $6.85 \mathrm{~d}$ was a reasonable assumption. These results imply leachability indexes $>18$ for the sensitivity study, which is a challenge to measurement capability and well above the grout leachability indexes of 9-10.

\begin{tabular}{|c|c|c|c|c|c|c|c|c|c|c|}
\hline \multirow{2}{*}{$\begin{array}{l}\text { Surrogate } \\
\text { sludge }\end{array}$} & \multirow{2}{*}{$\begin{array}{l}\text { Vit. } \\
\text { No. }\end{array}$} & \multicolumn{7}{|c|}{ TCLP extract concentration (mg/L) } & \multirow{2}{*}{$\begin{array}{c}\text { TCLP } \\
\text { fluid } \\
\text { No. }\end{array}$} & \multirow{2}{*}{$\begin{array}{l}\mathrm{pH} \text { after } \\
\text { extraction }\end{array}$} \\
\hline & & $\mathrm{Cd}$ & $\mathrm{Cr}$ & $\mathrm{Hg}^{\prime \prime}$ & $\mathrm{Pb}$ & $\mathrm{Se}$ & $\mathrm{Tl}$ & $\mathrm{U}$ & & \\
\hline \multirow{5}{*}{$\begin{array}{l}\text { Standard } \\
\text { sludge }\end{array}$} & 18 & $<0.002$ & 0.009 & NM & 0.010 & $<0.017$ & $<0.013$ & $<0.111$ & 1 & 4.93 \\
\hline & 19 & $<0.002$ & 0.011 & NM & 0.014 & $<0.017$ & $<0.013$ & $<0.111$ & 1 & 4.93 \\
\hline & 20 & $<0.002$ & $<0.007$ & NM & $<0.008$ & $<0.017$ & $<0.013$ & $<0.111$ & 1 & 4.98 \\
\hline & 21 & $<0.002$ & 0.007 & NM & 0.018 & $<0.017$ & $<0.013$ & $<0.111$ & 1 & 4.94 \\
\hline & 22 & $<0.002$ & $<0.007$ & NM & $<0.008$ & $<0.017$ & $<0.013$ & $<0.111$ & 1 & 4.93 \\
\hline $\begin{array}{c}\text { Max. bad } \\
\text { actors }\end{array}$ & 23 & $<0.002$ & 0.009 & NM & 0.014 & $<0.017$ & $<0.013$ & $<0.111$ & 1 & 4.92 \\
\hline \multirow[t]{2}{*}{ Std. } & 24 & $<0.002$ & 0.007 & $\mathrm{NM}$ & 0.015 & $<0.017$ & $<0.013$ & $<0.111$ & 1 & 4.95 \\
\hline & 25 & $<0.002$ & 0.007 & $N M$ & $<0.008$ & $<0.017$ & $<0.013$ & $<0.111$ & 1 & 4.93 \\
\hline \multicolumn{11}{|c|}{ TCLP UTS ${ }^{b}$} \\
\hline & & 0.190 & 0.860 & 0.025 & 0.370 & 0.160 & 0.078 & N/A ${ }^{c}$ & & \\
\hline
\end{tabular}

"Not measured for glass samples, because mercury compound not included in surrogate vitrified and would presumably volatilize, if included.

"The Universal Treatment Standard limits for the TCLP extract concentration.

$c_{N A}=$ Not applicable. 


\section{Hot-Cell Testing of Actual Tank Sludge and Surrogate Sludge}

Table 10 compares the elemental or ionic composition (on a dry basis) measured for the air-dried tank sludge sample with that calculated for the weighted-average surrogate sludge. The composition of the actual tank sludge sample was quite different from the weighted-average surrogate sludge used in laboratory testing. In fact, the composition of this actual tank sludge sample lay outside the range of measured tank sludge compositions used to design the weighted-average surrogate sludge. For this reason, a surrogate was designed specifically for this actual tank sludge sample and tested in the laboratory with the standard grout formulation. Table 11 lists the composition (dry basis) of this surrogates, and Table 10 compares its elemental/ionic composition (dry basis) to that of the actual sample and the weighted average surrogate.

This surrogate proved to be more "water demanding" than the weighted average surrogate. Whereas the weighted average water content of $51 \mathrm{wt} \%$ provided enough water for processing and mixing the weighted average surrogate into the standard grout in the laboratory, the new surrogate proved too dry with this water content and required a surrogate wet sludge water content of $80 \mathrm{wt} \%$ to make a wet mixable paste. Thus, a wet sludge content of $80 \mathrm{wt} \%$ was specified for use in the hot cell with the standard grout formulation for this tank sludge sample. The actual tank sludge sample proved to have "water demand" characteristics similar to the new surrogate and perhaps was even a little stiffer or "drier" than the surrogate.

Grout. The standard dry solid blend was premixed in a V-blender and placed in preweighed bottles for use in the cell. The dry-solid blend that was used follows:

Dry-Solid Blend
Indian Red Pottery Clay
Perlite
Fly Ash (Class F)
Blast-Furnace Slag
Portland Type I/II Cement

$\%$ of Total
8.0
20.0
19.1
32.9
20.0


Table 10. Comparison of the compositions of an actual tank sludge sample, the tank set weighted average surrogate, and the surrogate designed for the actual tank sludge sample

\begin{tabular}{|c|c|c|c|}
\hline \multirow[b]{2}{*}{ Element or ion } & \multicolumn{3}{|c|}{ Composition on a dry basis (mg/kg) } \\
\hline & Air-dried tank sludge sample & $\begin{array}{l}\text { Tank set weighted average } \\
\text { surrogate }\end{array}$ & Surrogate for actual sample \\
\hline \multicolumn{4}{|c|}{ RCRA Metals } \\
\hline $\mathrm{Ag}$ & & 36 & \\
\hline $\mathrm{Ba}$ & 400 & & 419 \\
\hline $\mathrm{Cd}$ & 50 & 42 & 52 \\
\hline $\mathrm{Cr}$ & 600 & 208 & 628 \\
\hline $\mathrm{Hg}$ & 200 & 61 & 209 \\
\hline $\mathrm{Ni}$ & 400 & & 419 \\
\hline $\mathrm{Pb}$ & 2,000 & 564 & 2,095 \\
\hline $\mathrm{Se}$ & & 95 & \\
\hline $\mathrm{Tl}$ & & 33 & \\
\hline \multicolumn{4}{|c|}{ Process Metals } \\
\hline $\mathrm{Al}$ & 25,800 & 7,026 & 27,021 \\
\hline $\mathrm{Ca}$ & 96,000 & 79,318 & 100,544 \\
\hline Cs & 3 & & \\
\hline $\mathrm{Co}$ & 40 & & \\
\hline $\mathrm{Fe}$ & 8,600 & 2,875 & 9,007 \\
\hline $\mathrm{K}$ & 14,400 & 30,059 & 15,082 \\
\hline $\mathrm{Mg}$ & 13,500 & 17,539 & 14,139 \\
\hline $\mathrm{Mn}$ & 800 & & \\
\hline $\mathrm{Na}$ & 110,000 & 163,869 & 115,159 \\
\hline $\mathrm{Si}$ & 15,300 & & 16,024 \\
\hline $\mathrm{Sr}$ & 5,600 & 314 & 5,865 \\
\hline Th & 57,400 & 12,191 & 60,117 \\
\hline $\mathrm{U}$ & 27,600 & 23,793 & 28,907 \\
\hline $\mathrm{Zn}$ & 800 & & 838 \\
\hline Bromide & 700 & & 733 \\
\hline Carbonate & 115,000 & 86,715 & 120,444 \\
\hline Chloride & 3,700 & 5,397 & 3,875 \\
\hline Fluoride & 1,900 & 1,327 & 1,990 \\
\hline Nitrate & 179,000 & 491,442 & 187,474 \\
\hline Phosphate & 29,500 & & 30,896 \\
\hline Sulfate & 7,000 & 3,763 & 7,331 \\
\hline Total & 712,643 & 925,628 & 745,447 \\
\hline \multicolumn{4}{|c|}{ wt \% } \\
\hline Total & $71 \%$ & $93 \%$ & $75 \%$ \\
\hline
\end{tabular}




\begin{tabular}{|c|c|}
\hline Compound & (wt \%) \\
\hline $\mathrm{Al}(\mathrm{OH})_{3}$ & $7.8119 \%$ \\
\hline $\mathrm{Ba}(\mathrm{OH})_{2} .8 \mathrm{H}_{2} \mathrm{O}$ & $0.0962 \%$ \\
\hline $\mathrm{Ca}(\mathrm{OH})_{2}$ & $3.7156 \%$ \\
\hline $\mathrm{CdO}$ & $0.0060 \%$ \\
\hline $\mathrm{Na}_{2} \mathrm{Cr}_{2} \mathrm{O}_{7} \cdot 2 \mathrm{H}_{2} \mathrm{O}$ & $0.1801 \%$ \\
\hline $\mathrm{Fe}_{2} \mathrm{O}_{3}$ & $1.2878 \%$ \\
\hline $\mathrm{HgCl}_{2}$ & $0.0284 \%$ \\
\hline $\mathrm{KNO}_{3}$ & $3.8997 \%$ \\
\hline $\mathrm{MgO}$ & $2.3437 \%$ \\
\hline $\mathrm{NaOH}$ & $13.5932 \%$ \\
\hline $\mathrm{NiO}$ & $0.0533 \%$ \\
\hline $\mathrm{PbO}$ & $0.2256 \%$ \\
\hline $\mathrm{SiO}_{2}$ & $3.4281 \%$ \\
\hline $\mathrm{Sr}\left(\mathrm{NO}_{3}\right)_{2}$ & $1.4166 \%$ \\
\hline $\mathrm{Th}\left(\mathrm{NO}_{3}\right)_{4} \cdot 4 \mathrm{H}_{2} \mathrm{O}$ & $14.3045 \%$ \\
\hline $\mathrm{UO}_{2}\left(\mathrm{NO}_{3}\right)_{2} \cdot 6 \mathrm{H}_{2} \mathrm{O}$ & $6.0976 \%$ \\
\hline $\mathrm{ZnO}$ & $0.1043 \%$ \\
\hline $\mathrm{NaBr}$ & $0.0944 \%$ \\
\hline $\mathrm{CaCO}_{3}$ & $20.0888 \%$ \\
\hline $\mathrm{NaCl}$ & $0.6266 \%$ \\
\hline $\mathrm{NaF}$ & $0.4398 \%$ \\
\hline $\mathrm{NaNO}_{3}$ & $10.4097 \%$ \\
\hline Tributylphosphate (TBP) & $8.6640 \%$ \\
\hline $\mathrm{Na}_{2} \mathrm{SO}_{4}$ & $1.0841 \%$ \\
\hline Total & $100.0000 \%$ \\
\hline
\end{tabular}

The hot-cell work with surrogate grout utilized $661.05 \mathrm{~g}$ of surrogate sludge containing $80 \%$ water, together with $540.76 \mathrm{~g}$ of the dry blend above. Prior to use, the two were mixed for $10 \mathrm{~min}$ at low speed and 2 min at high speed in the Hobart mixer.

The same blending technique was used with the actual tank sludge samples, except that since the centrifuged starting sludge contained only $50.5 \%$ water, instead of the $80 \%$ with the surrogate, water was added to achieve the desired amount of water.

The method of preparation of grout with actual tank waste included the use of $296.5 \mathrm{~g}$ of centrifuged sludge containing $50.5 \%$ water, in addition to $600.31 \mathrm{~g}$ of the dry blend and $437.34 \mathrm{~g}$ of makeup water, added as deionized water. Following the same mixing scheme and times used for the surrogate sludge, the resulting paste appeared thicker than when using the surrogate sludge. 
Table 12 lists the performance test results for the actual tank sludge grout and its surrogate. Results with both the surrogate waste and with the actual tank waste showed that at $24 \mathrm{~h}$ no bleed water was observed on either of the two sealed cylinders of grout. The grout slurry produced from actual sludge never formed any bleed water; however, the grout slurry containing surrogate waste produced a trace that was too small to be measured and which was taken up by the grout over the first several hours. Both the surrogate and actual waste-containing grout reached very high-penetration resistances after only $7 \mathrm{~d}$. Both grouts had nearly the same penetration resistance after $24 \mathrm{~h}$; however, the grout containing actual waste quickly accelerated in strength after that time. Grout containing the surrogate waste achieved a penetration resistance of 6,440 psi at $7 \mathrm{~d}$; the grout containing the actual tank sludge achieved $8,400 \mathrm{psi}$. The more rapid rise in penetration resistance for grout containing the actual tank waste is evident from Table 12.

\begin{tabular}{|c|c|c|c|}
\hline \multicolumn{2}{|c|}{ Performance measurement } & Surrogate tank sludge grout & Actual tank sludge grout \\
\hline \multicolumn{2}{|c|}{ Grout density $(\mathrm{g} / \mathrm{mL})$} & 1.53 & 1.51 \\
\hline \multicolumn{2}{|c|}{ Volume ratio of grout to wet sludge } & 1.35 & 1.40 \\
\hline \multicolumn{2}{|c|}{ 28-d free water (vol \%) } & 0.0 & 0.0 \\
\hline \multirow{5}{*}{$\begin{array}{l}\text { Penctration } \\
\text { resistance } \\
\text { (psi) }\end{array}$} & l d & 1,420 & 1,400 \\
\hline & $2 d$ & 2,080 & 3,680 \\
\hline & $3 d$ & 3,360 & 5,520 \\
\hline & $4 d$ & 4,880 & 6,320 \\
\hline & $7 d$ & 6,440 & 8,400 \\
\hline
\end{tabular}

Table 13 compares the TCLP performance of the untreated sludges, the grouted sludges, and the vitrified sludges. The untreated sludge was characteristically hazardous for mercury and met UTS limits for all the measured RCRA metals, except mercury and chromium. From Table 13, grouting and vitrification significantly improved the TCLP performance, and the TCLP extract concentrations after treatment were well below the UTS limits, although vitrification presumably volatilized the mercury. 


\begin{tabular}{|c|c|c|c|c|c|c|c|c|}
\hline \multirow{2}{*}{ Analyte } & \multicolumn{2}{|c|}{ Raw wet sludge } & \multicolumn{2}{|c|}{ Grout } & \multicolumn{2}{|c|}{ Glass } & \multirow{2}{*}{ Char. limit } & \multirow{2}{*}{ UTS limit } \\
\hline & Actual & Surrogate $^{a}$ & Actual & Surrogate $^{a}$ & Actual & Surrogate ${ }^{b}$ & & \\
\hline \multicolumn{9}{|c|}{$\mathrm{mg} / \mathrm{L}$} \\
\hline $\mathrm{Ag}$ & 0.145 & 0.008 & $<0.02$ & $<0.002$ & $<0.033$ & $<0.006$ & 5 & 0.3 \\
\hline As & 0.0065 & $<0.008$ & 0.0061 & $<0.008$ & $<0.0084$ & $<0.017$ & 5 & 5 \\
\hline $\mathrm{Ba}$ & 2.34 & 0.419 & 0.113 & 1.76 & 0.33 & 1.30 & 100 & 7.6 \\
\hline $\mathrm{Cd}$ & 0.133 & 0.904 & $<0.02$ & $<0.002$ & $<0.03$ & $<0.002$ & 1 & 0.19 \\
\hline $\mathrm{Cr}$ & 0.93 & 5.95 & 0.006 & 0.014 & 0.037 & 0.008 & 5 & 0.86 \\
\hline $\mathrm{Hg}$ & 0.324 & 1.54 & 0.00363 & 0.0002 & $<0.0033$ & $\mathrm{NM}^{e}$ & 0.2 & 0.025 \\
\hline $\mathrm{Ni}$ & 0.145 & 0.047 & $<0.02$ & $<0.004$ & 0.19 & 0.367 & $\mathrm{~N} / \mathrm{A}^{d}$ & 5 \\
\hline $\mathrm{Pb}$ & 0.232 & 0.111 & 0.021 & 0.009 & 0.60 & 0.198 & 5 & 0.37 \\
\hline $\mathrm{Se}$ & 0.0192 & 0.118 & 0.0133 & 0.053 & $<0.0084$ & $<0.022$ & 1 & 0.16 \\
\hline $\mathrm{Tl}$ & $<0.005$ & 0.486 & $<0.005$ & $<0.006$ & $<0.17$ & $<0.013$ & N/A & 0.078 \\
\hline
\end{tabular}

Glass. This phase of the test work involved three glasses: a borosilicate reference glass provided by the Savannah River Technology Center (SRTC) known as the ARM glass, a soda-lime surrogate glass made from surrogate sludge representing the actual tank sludge sample, and a soda-lime glass prepared from the actual tank sludge sample. The ARM glass contains neither actual nor simulated waste. Rather, it is a reference glass used as a control for the PCT. The ARM glass was provided as a single chunk of glass and was therefore not melted, but rather size-reduced prior to leaching with the PCT. The leaching performance of this glass has been well documented at SRTC and is therefore used as a control (Jantzen et al, 1992). The surrogate glass was based upon a sludge composition that best represented the actual tank sludge sample. 
The refined formulation was used to prepare two of the glasses, one with the actual tank sludge sample and one with its surrogate. This glass formulation follows:

$\begin{array}{ll}\text { Waste } & 25.0 \mathrm{~g} \text { of dry sludge (dried at } 105^{\circ} \mathrm{C} \text { for } 24 \mathrm{~h} \text { ) } \\ \text { Precipitated silica } & 14.2 \mathrm{~g} \\ \text { Calcium carbonate } & 8.12 \mathrm{~g}\end{array}$

The density of the glass was not checked but was expected to be $2.87 \mathrm{~g} / \mathrm{cc}$ per the SRTC test work with the surrogate of the actual tank sludge sample. The surrogate-based glass produced a button of glass weighing $32.73 \mathrm{~g}$; the test with actual tank waste resulted in $38.26 \mathrm{~g}$, implying less decomposition and off-gassing for the actual dried sludge upon vitrification. The glasses produced were dark brown in color and were found to be much softer than the borosilicate-based ARM glass provided by SRTC, based on crushing and screening activities.

The two glasses produced from the actual tank sludge sample and its surrogate were found to stick to the bottom of the platinum crucibles. The $1300^{\circ} \mathrm{C}$ crucibles were removed from the furnace, using special tongs adapted for use with the manipulator. Once removed they were quickly quenched in ice water, hoping that the thermal shock would loosen the glass from the crucible. This step alone did not work, so the bottoms of the room-temperature crucibles were placed just below the surface of liquid nitrogen pumped into the cell. The crucibles had a small amount of clean glass quartz wool positional in the top of the crucible so that glass could not be ejected during cooling. Again, this step alone failed to release the glass from the crucible; however, in one case, upon setting overnight, the glass shattered and when tapped on the bottom, all the glass broke free-a type of delayed reaction. With the other crucible, following the use of liquid nitrogen, quartz wool was placed inside the crucible and the bottom of the crucible was repeatedly dropped onto the cell working surface from a height of approximately 4 in. until it too shattered.

Table 13 lists the TCLP extract concentrations of the glass produced from both the actual tank sludge sample and its surrogate. It also compares these results with those of the untreated sludges and the grouted sludges. The untreated sludge was characteristically hazardous for mercury and met UTS limits for all the measured RCRA metals, except mercury and chromium. From Table 13, vitrification and grouting significantly improved the TCLP performance. The TCLP extract concentrations after treatment were well below the UTS limits, although vitrification presumably volatilized the mercury. 
Table 14 lists the leachate concentrations from the PCT tests, comparing the ARM glass, the actual sludge SLS glass, and the surrogate SLS glass. The individual glasses were self-consistent among the triplicate results. The two SLS glasses were fairly consistent with each other, but, not surprisingly, significantly different from the borosilicate glass. In addition, Table 14 also lists the radioisotopic content of the actual waste glass PCT leachates.

A sample of the sludge used in the melt crucible was counted by gamma spectroscopy along with an NBS standard to ensure that the system was operating properly. Additionally an 18 gram sample of the hot glass was also counted in order to establish the amounts volatilized. Table 15 summarizes these results, implying $57.7 \%$ of the ${ }^{137} \mathrm{Cs}, 18.5 \%$ of the ${ }^{60} \mathrm{Co}$, and $9.7 \%$ of the ${ }^{154} \mathrm{Eu}$ were lost through volatilization from the crucible glass.

\section{Summary and Conclusions}

The surrogate sludges were stabilized in grout at a wet-sludge loading of up to $60 \mathrm{wt} \%$ with little or no secondary waste generation, resulting in a volume increase of $40-50 \mathrm{vol} \%$ for grout. The high water content of the sludges limited the sludge Joading to $60 \mathrm{wt} \%$, because higher loadings can result in free water, which violates the waste acceptance criteria of disposal facilities. Dewatering the sludge may allow higher waste loadings, with correspondingly lower volume increases, without sacrificing the Toxicity Characteristic Leaching Procedure (TCLP) performance or leach resistance. The grout strength does decline as the sludge loading increases above $60 \mathrm{wt} \%$. However, a strong monolithic solid is not usually a waste acceptance criterion, although it does decrease the surface area available for leaching and consequently improves leach resistance. Grouts can stabilize the RCRA metals and pass the TCLP test, including that for mercury, potentially a problem species for the tank sludges. The leachability indexes (ANSI/ANS-16.1) measured for the sensitivity testing grouts ranged from 9.2 to 10.0 and from 9.3 to 10.5 for ${ }^{85} \mathrm{Sr}$ and ${ }^{137} \mathrm{Cs}$, respectively. 


\begin{tabular}{|c|c|c|c|c|c|c|c|c|c|}
\hline \multirow{2}{*}{ Analyte } & \multicolumn{3}{|c|}{ Borosilicate ARM glass } & \multicolumn{3}{|c|}{ Soda-lime actual sludge glass } & \multicolumn{3}{|c|}{ Soda-lime surrogate glass } \\
\hline & ARM010 & ARM033 & ARM045 & нотозо & HOT042 & HOTOSO & SUR015 & SUR029 & SUR044 \\
\hline \multicolumn{10}{|c|}{$\mathrm{mg} / \mathrm{L}$} \\
\hline $\mathrm{Al}$ & 4.97 & 4.61 & 4.83 & 1.06 & 1.01 & 1.08 & 0.83 & 0.85 & 0.863 \\
\hline B & 12.62 & 13.18 & 12.65 & $<0.080$ & $<0.080$ & $<0.080$ & $<0.080$ & $<0.080$ & $<0.080$ \\
\hline $\mathrm{Ca}$ & $<2.00$ & $<2.0$ & $<2.00$ & 23.74 & 23.26 & 23.26 & 22.91 & 23.26 & 23.69 \\
\hline $\mathrm{Fe}$ & $<0.240$ & $<0.240$ & $<0.240$ & $<0.240$ & $<0.240$ & $<0.240$ & $<0.240$ & $<0.240$ & $<0.240$ \\
\hline $\mathrm{K}$ & $<0.320$ & $<0.320$ & $<0.320$ & 2.428 & 2.410 & 2.531 & 2.910 & 2.924 & 2.980 \\
\hline $\mathrm{Mg}$ & $<0.240$ & $<0.240$ & $<0.240$ & $<0.240$ & $<0.240$ & $<0.240$ & $<0.240$ & $<0.240$ & $<0.240$ \\
\hline $\mathrm{Na}$ & 31.08 & 31.98 & 31.01 & 23.56 & 23.37 & 23.71 & 36.15 & 37.04 & 37.81 \\
\hline $\mathrm{Si}$ & 52.49 & 52.62 & 51.28 & 28.52 & 28.80 & 28.45 & 33.37 & 34.16 & 34.67 \\
\hline $\mathrm{Sr}$ & 0.015 & 0.013 & 0.012 & 0.069 & 0.069 & 0.068 & 0.682 & 0.698 & 0.712 \\
\hline $\mathrm{Ti}$ & 0.009 & 0.010 & 0.009 & $<0.004$ & $<0.004$ & $<0.004$ & $<0.004$ & $<0.004$ & $<0.004$ \\
\hline $\mathrm{Zn}$ & 0.279 & 0.234 & 0.191 & 0.095 & 0.069 & 0.074 & 0.130 & 0.215 & 0.083 \\
\hline \multicolumn{10}{|c|}{ Radioactivity content of PCT leachate } \\
\hline \multicolumn{4}{|c|}{${ }^{137} \mathrm{Cs}, \mathrm{Bq} / \mathrm{mL}$} & 120 & 120 & 120 & & & \\
\hline \multicolumn{4}{|c|}{ Gross Beta, $\mathrm{Bq} / \mathrm{mL}$} & 4800 & 4800 & 4700 & & & \\
\hline \multicolumn{4}{|c|}{${ }^{90} \mathrm{Sr} /{ }^{89} \mathrm{Sr}, \mathrm{Bq} / \mathrm{mL}$} & 25 & 42 & 6.3 & & & \\
\hline \multicolumn{4}{|c|}{ Thorium, mg/L } & $<1.65$ & $<1.65$ & $<1.65$ & & & \\
\hline \multicolumn{4}{|c|}{ Uranium, $\mathrm{mg} / \mathrm{L}$} & $<3.30$ & $<3.30$ & $<3.30$ & & & \\
\hline
\end{tabular}

Table 15. Composition by gamma spectroscopy of glass sample made from actual tank sludge sample

\begin{tabular}{|c|c|c|c|}
\hline \multirow{2}{*}{ Radioisotope } & \multicolumn{2}{|c|}{ Concentration in glass $(\mathrm{kBq} / \mathrm{g})$} & \multirow{2}{*}{ \% Retained in glass } \\
\cline { 2 - 4 } & Initially in sludge & Measured in glass & \\
\hline${ }^{137} \mathrm{Cs}$ & 988 & 418 & 42.3 \\
\hline${ }^{60} \mathrm{Co}$ & 74.0 & 60.3 & 81.5 \\
\hline${ }^{154} \mathrm{Eu}$ & 72.1 & 65.1 & 90.3 \\
\hline
\end{tabular}


The surrogate sludges were stabilized in glass at a waste oxide loading of $40-50 \mathrm{wt} \%$, resulting in a net volume decrease of 50-60 vol \%. Waste glass logs are not annealed and subsequently fracture, leaving a high surface area available for leaching; however, the superior leach resistance of glass overcomes this problem. Although RCRA metals incorporated into the glass matrix are stabilized and leach resistant, mercury is volatilized and must be treated in the off-gas. In general, the glass leachate concentrations for strontium and cesium were below ICP-MS detection limits, but the leachability index for strontium and cesium from glass was estimated at $>18$, implying an effective diffusion coefficient 8 orders of magnitude lower than that measured for grout and 12 orders of magnitude lower than that recommended by the Nuclear Regulatory Commission.

The actual tank sludge sample gave results similar to the surrogate designed for this sample and essentially confirmed the conclusions from the surrogate work.

This work suggests that these sludges can be stabilized in either grout or glass for final disposal. These results were generated using a surrogate based on limited waste characterization data and were verified using only a single actual waste sample. Confirmation of these results with more actual tank sludge samples must be done prior to final acceptance of either technique, and additional work is required before full-scale processing. A threefold decrease in final waste form volume for vitrification as compared to grout was noted, not including the secondary waste generation from off-gas treatment. From the standpoints of volume reduction and leachability index, the performance of the glass waste form for this waste stream was superior to that of grout, although the grout had a superior TCLP performance. Other criteria, such as secondary waste generation, overall economics, risk, and stakeholder preferences, must be considered in selecting the process for treatment and disposal of this sludge.

\section{Acknowledgments}

The authors gratefully acknowledge the refinements made in the glass formulation to allow lower furnace temperatures made by Mary Andrews and John Harbour of the Savannah River Technology Center; the laboratory and hot-cell support of Cathy McKeown, Jim Travis, and Russ Trotter, of the Chemical Technology Division; the support of John Plodinec and Bill Holtzscheiter of the DOE Tanks Focus Area; the support of Cavanaugh Mims and Gary Riner of the Department of Energy-Oak Ridge Operations; and the financial support of the Tanks Focus Area and the Department of Energy. 


\section{References}

American Nuclear Society, American National Standard Measurement of the Leachability of Solidified LowLevel Radioactive Wastes by as Short-Term Test Procedure, ANSI-ANS-16.1-1986, prepared by the American Nuclear Society Standards Committee Working Group ANS16.1, published by the American Nuclear Society, La Grange Park, Ill., approved April 14, 1986, by the American National Standards Institute, Inc.

J. R. Conner, Chemical Fixation and Solidification of Hazardous Wastes, Van Nostrand Reinhold, New York, 1990.

EPA, EPA Handbook on Vitrification Technologies for Treatment of Hazardous and Radioactive Waste, EPA/625/R-92/002, U.S. Environmental Protection Agency, Office of Research and Development, Washington, D.C., May 1992.

T. M. Gilliam and J. A. Loflin, Leachability Studies of Hydrofracture Grouts, ORNL/TM-9879, Oak Ridge National Laboratory, November 1986.

T. M. Gilliam, "Leach Testing of Hydrofracture Grouts Containing Hazardous Waste," J. of the Underground Injection Practices Council, Vol. I, p. 192, 1986.

T. M. Gilliam, E. W. McDaniel, L. R. Dole, H. R. Friedman, J. A. Loflin, A. J. Mattus, I. L. Morgan, O. K. Tallent, and G. A. West, Summary Report on the Development of a Cement-Based Formula to Immobilize Hanford Facility Waste, ORNL/TM-10141, Oak Ridge National Laboratory, September 1987.

T. M. Gilliam, et al., "Vitrification of Waste Water Treatment Sludge Volume II: Crucible-Scale Formulation Development Studies with Actual West End Treatment Facility Sludge Samples," Scientific Basis for Nuclear Waste Management, XX, Materials Research Society, Pittsburgh, Pa., 1996.

IAEA, Improved Cement Solidification Of Low- and Intermediate-Level Radioactive Wastes, Technical Report Series No. 350, International Atomic Energy Agency, Vienna, 1993. 
C. M. Jantzen, N. E. Bibler, D. C. Beam, W. G. Ramsey and B. J. Waters, Nuclear Waste Glass Product Consistency Test (PCT)-Version 5.0 (U), WSRC-TR-90-539, Rev. 2, Westinghouse Savannah River Co., January 1992. (See also ASTM, vol. 1502.)

C. M. Jantzen, N. D. Hutson, T. M. Gilliam, A. Bleier, and R. D. Spence, Vitrification Treatability Studies of Actual Waste Water Treatment Sludges, U.S. DOE Report WSRC-MS-95-0064, Savannah River Technology Center, Westinghouse Savannah River Co., Aiken, S.C., and Proceedings of Waste Management '95 ,1995.

E. W. McDaniel, T. M. Gilliam, and L. R. Dole, Recommended Major Grout Components, ORNL Milestone No. 32, Project B-475, Transportable Grout Facility, Oak Ridge National Laboratory, April 15, 1984.

M. B. Sears, J. L. Botts, R. N. Ceo, J. J. Ferrada, W. H. Griest, J. M. Keller, and R. L. Schenley, Sampling and Analysis of Radioactive Liquid Wastes and Sludges in the Melton Valley and Evaporator Facility Storage Tanks at ORNL, ORNL/TM-11652, Oak Ridge National Laboratory, September 1990.

R. D. Spence, W. D. Bostick, E. W. McDaniel, T. M. Gilliam, J. L. Shoemaker, O. K. Tallent, I. L. Morgan, B. S. Evans-Brown, and K. E. Dodson, Immobilization of Technetium in Blast Furnace Slags, presented at the Third International Conference on the Use of Fly Ash, Silica Fume, Slag and Natural Pozzolans in Concrete, Trondheim, Norway, June 19-24, 1989.

J. M. Stevels, Progress in the Theory of the Physical Properties of Glass, Elsevier, Amsterdam, 1948.

J. M. Stevels, Glass Ind., 35, 69, 1954.

J. M. Stevels, Philips' Tec. Rundsch., 22, 337-349, 1960/61.

Arun K. Varshneya, Fundamentals of Inorganic Glasses, Academic Press, Inc., Publishers, San Diego, Calif., 1994.

M. B. Volf, Chemical Approach to Glass, Glass Science and Technology, 7, Elvsevier, New York, 1984. 


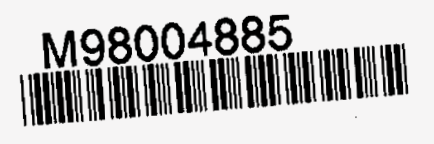

Report Number (14) ORNL/CP--93287
CONE $-980318-$

Publ. Date (11) 19980303

Sponsor Code (18) DOE/EM, XF

UC Category (19) UC-2000,DOE/ER 